\title{
Gambaran Polifarmasi Pasien Geriatri Dibeberapa Poliklinik RSUP Dr. M. Djamil Padang
}

Aryaldy Zulkarnaini ${ }^{1}$, Rose Dinda Martini ${ }^{2}$

\begin{abstract}
Abstrak
Polifarmasi adalah penggunaan lebih atau sama 5 macam obat secara bersamaan setiap hari. Paling sering disalahgunakan sebagai terapi untuk masalah kesehatan pada pasien geriatri. Penyakit kronik pada pasien geriatri menyebabkan meningkatnya jumlah peresepan obat yang diberikan kepada pasien. Reaksi efek samping obat, termasuk interaksi obat pada pasien geriatri yang merupakan masalah umum terjadi di rumah sakit dan merupakan penyebab penting pada tingkat morbiditas dan mortalitas. Tujuan penelitian ini adalah mengetahui gambaran penyakit kronis yang multipatologis dengan prevalensi polifarmasi pada pasien geriatri di poliklinik rawat jalan RSUP M.Djamil Padang. Penelitian ini merupakan studi observasional. Populasi sampel pada penelitian ini adalah seluruh pasien geriatri (usia $\geq 60$ tahun) yang datang ke Instalasi rawat jalan. Terdapat sebanyak 360 (58.25\%) laki-laki dan 258 (41.75\%) perempuan dari 618 pasien. Kami menemukan polifarmasi pada 400 pasien (64.72\%). Kesimpulan penelitian ini polifarmasi sangat berhubungan erat dengan tingginya morbiditas penyakit. Penyakit jantung memiliki tingkat yang tinggi untuk polifarmasi.
\end{abstract}

Kata kunci: polifarmasi, geriatri

Abstract

Polypharmacy is the use of more or more 5 kinds of drugs simultaneously every day. Most often misused as a therapy for health problems in geriatric patients. Chronic diseases in geriatric patients cause an increase in the number of prescription drugs given to patients. Reactions of drug side effects, including drug interactions in geriatric patients which are common problems in hospitals and are important causes of morbidity and mortality. The objective of this study was to find out the description of a chronic multipatological disease with the prevalence of polypharmacy in geriatric patients at the outpatient clinic of M.Djamil Hospital Padang. This research is observational research. The sample population in this study were all geriatric patients (age $\geq 60$ years) who came to the outpatient installation. There were 360 (58.25\%) men and 258 (41.75\%) women of 618 patients. We found polypharmacy in 400 patients (64.72\%). The conclusion of this study polypharmacy is very closely related to the high morbidity of the disease. Heart disease has a high level of polypharmacy.

Keywords: polifarmasi, geriatric

Affiliasi penulis: 1. Program Pendidikan Dokter Spesialis-1 IImu Penyakit Dalam FK Unand, 2. Subbagian Geriatrii Bagian IImu Penyakit Dalam FK Unand/RSUP M Djamil Padang

Korespondensi: Aryaldy Zulkarnaini, Email:dr.aryaldy.int@gmail.com Telp: 08116612633

\section{PENDAHULUAN}

Salah satu tantangan terbesar yang dihadapi sistem kesehatan secara global saat ini adalah meningkatnya jumlah pasien dengan penyakit kronis. Penyakit kronik pada pasien geriatri menyebabkan meningkatnya jumlah peresepan obat yang diberikan kepada pasien. ${ }^{(1)}$ Pemberian banyak obat atau polifarmasi didefinisikan sebagai penggunaan beberapa obat, sebagian besar penelitian terbaru yang dilakukan di Eropa dan Australia menetapkan bahwa polifarmasi adalah penggunaan lebih dari 
lima macam obat. Obat-obatan adalah yang paling sering digunakan dan disalahgunakan sebagai terapi untuk masalah kesehatan pada pasien geriatri. ${ }^{(2)}$ Layanan kesehatan profesional bagian geriatri sangat bergantung pada farmakoterapi untuk meringankan gejala, meningkatkan kualitas hidup dan status fungsional, menyembuhkan atau pengelolaan penyakit yang berpotensi untuk memperpanjang kelangsungan hidup. ${ }^{(1)(2)}$

Prevalensi polifarmasi telah dianalisis dalam banyak studi dengan hasil yang berbeda dalam hal pengaturan klinis. Biasanya polifarmasi ini terkait erat dengan jumlah penyakit atau multimorbiditi. Prevalensi multimorbiditi pada pasien geriatri berkisar antara 35 persen menjadi 80 persen, tergantung pada metode pengumpulan data, definisi dan kondisi kronis multimorbiditi, jumlah dan kondisi kronis yang termasuk dalam analisis. (3) Sebuah penelitian dari pusat pelayanan kesehatan primer di Riyadh Arab Saudi, menemukan prevalensi polifarmasi $89,1 \%$. Selain multimorbiditi, penyakit kronik spesifik seperti hipertensi, penyakit jantung koroner, gagal jantung, penyakit paru obstruksi, gagal ginjal kronik dan diabetes melitus adalah prediktor dari polifarmasi. ${ }^{(1)}(3)$

Pada usia 60 tahun ke atas terjadi proses penuaan yang bersifat universal berupa kemunduran dari fungsi biosel, jaringan, organ, bersifat progresif, berubahan secara bertahap, akumulasi dan intrinsik. Proses penuaan menyebabkan terjadinya perubahan pada berbagai organ di dalam tubuh seperti gastrointestinal, sistem genitouria, sistem imunologi, sistem serebrovaskular, sistem saraf pusat dan sebagainya. (4) Oleh sebab itu, penyakit pada populasi usia lanjut berbeda perjalanan dan penampilannya dengan yang terdapat pada populasi lain, dimana penyakit bersifat multipatologi, degeneratif, saling terkait, kronis, cenderung menyebabkan kecatatan lama sebelum terjadinya kematian dan dalam pengobatan sering terdapat polifarmasi. ${ }^{(5)}$ Pada usia lanjut yang menderita lebih dari satu penyakit dan mendapat berbagai macam obat secara bersamaan merupakan kelompok yang rentan terhadap interaksi obat. ${ }^{(6)}$ Risiko interaksi obat meningkat sesuai dengan jumlah obat yang diresepkan dan pasien geriatri biasanya mendapatkan obat yang lebih banyak dibandingkan pasien usia lainnya. ${ }^{(7)}$

Reaksi efek samping obat, termasuk interaksi obat pada pasien geriatri yang merupakan masalah umum terjadi di rumah sakit dan merupakan penyebab penting pada tingkat morbiditas dan mortalitas. (8) (9) Menurut penelitian Monita Cahya Ningsih (2004) tentang interaksi obat pada pasien di poliklinik geriatri RS Dr. Cipto Mangunkusumo didapatkan rata-rata pasien mendapatkan 5 macam obat secara bersamaan. ${ }^{(10)}$ Diketahui $68 \%$ dari 150 pasien teridentifikasi mengalami interaksi obat dan $11,6 \%$ dari interaksi obat tersebut dianggap sebagai interaksi yang menuntut perhatian klinik. (11) (9)

Berdasarkan latar belakang diatas, tujuan dari peneliti adalah mengetahui gambaran penyakit kronis yang multipatologis dengan prevalensi polifarmasi pada pasien geriatri di poliklinik rawat jalan RSUP M.Djamil Padang.

\section{METODE}

Penelitian dilakukan di Instalasi Rawat Jalan RSUP M.Djamil Padang. Penelitian ini merupakan penelitian yang bersifat observasional. Populasi sampel pada penelitian ini adalah seluruh pasien geriatri (usia $\geq 60$ tahun) yang datang ke Instalasi rawat jalan RSUP M.Djamil Padang setiap hari rabu bulan April 2015, di poliklinik khusus geriatri, poliklinik khusus rematologi, poliklinik jantung, poliklinik paru, poliklinik syaraf, dan poliklinik urologi. 
Kriteria inklusi adalah seluruh pasien dengan umur $\geq 60$ tahun. Pasien rawat jalan di poliklinik RSUP M.Djamil Padang. Pasien yang menderita penyakit kronis yang berobat rutin setiap bulan. Kriteria eklusi adalah pasien yang tidak mengambil resep obat dan pasien yang diputuskan untuk dilakukan perawatan paliatif dirumah sakit.

\section{HASIL}

Karakteristik penelitian ini adalah mencatat jenis kelamin, usia, jumlah kunjungan ke masingmasing poliklinik RSUP M.Djamil Padang pada hari rabu dalam satu bulan. Terdapat sebanyak 360 (58.25\%) laki-laki dan 258 (41.75\%) perempuan. Usia terbanyak pasien geriatri yang melakukan kunjungan adalah usia 60-64 tahun dan rerata usia pasien geriatri adalah 65-69 tahun, dengan usia tertua adalah 88 tahun.

Tabel 1. Jumlah pasien geriatric berdasarkan jenis kelamin

\begin{tabular}{ccc}
\hline Jenis Kelamin & Jumlah Pasien & $\%$ \\
\hline Laki-laki & 360 & 58.25 \\
Perempuan & 258 & 41.75 \\
& 618 & 100 \\
\hline
\end{tabular}

Tabel 2. Jumlah pasien geriatri berdasarkan usia

\begin{tabular}{ccc}
\hline Usia (Tahun) & Jumlah Pasien (n) & $\%$ \\
\hline $60-64$ & 231 & 37.38 \\
$65-69$ & 162 & 26.22 \\
$70-74$ & 136 & 22.01 \\
$75-79$ & 62 & 10.02 \\
$\geq 80$ & 27 & 4.37 \\
\hline & 618 & 100 \\
\hline
\end{tabular}

Tabel 3. Jumlah pasien masing-masing poliklinik khusus

\begin{tabular}{lcc}
\hline Poliklinik Khusus & $\begin{array}{c}\text { Jumlah Pasien } \\
\text { (n) }\end{array}$ & $\%$ \\
\hline Geriatri & 209 & 33.81 \\
Reumatologi & 50 & 8.09 \\
Jantung & 278 & 44.98 \\
Paru & 34 & 5.51 \\
Saraf & 26 & 4.23 \\
Urologi & 6 & 0.97 \\
2 poliklinik & 15 & 2.42 \\
\hline
\end{tabular}

Tabel 4. Kelompok jenis penyakit pasien geriatri pada poliklinik khusus rawat jalan

\begin{tabular}{ll}
\hline Poliklinik & Jenis Penyakit \\
\hline Geriatri & $\begin{array}{l}\text { Osteoarthritis, Diabetes mellitus, } \\
\text { Dislipidemia, Penyakit lambung, } \\
\text { Hipertensi, Penyakit Intestinal, Sirosis } \\
\text { hepatis, GOUT, Penyakit tiroid, CKD, } \\
\text { Anemia, Demensia }\end{array}$ \\
Rematologi & OA, GOUT, Osteoporosis, RA \\
Jantung & $\begin{array}{l}\text { Atrial fibrilasi (AF), Penyakit Jantung } \\
\text { Koroner, Gagal jantung, Hipertensi }\end{array}$ \\
Paru & $\begin{array}{l}\text { Penyakit paru obstruksi kronik, Asma } \\
\text { bronchial,CAP }\end{array}$ \\
Syaraf & $\begin{array}{l}\text { Cerebrovaskular disease (CVD), } \\
\text { Demensia }\end{array}$ \\
\hline
\end{tabular}

Tabel 5. Obat terbanyak yang diresepkan pada pasien geriatric di Poliklinik RS. M Djamil

\begin{tabular}{clc} 
No. & Nama obat & $\begin{array}{c}\text { Jumlah obat yang } \\
\text { diresepkan }\end{array}$ \\
\hline 1. & Lansoprazol & 332 \\
2. & Simvastatin & 277 \\
3. & Candesartan & 253 \\
4. & Asam Asetil salisilat & 225 \\
5. & Bisoprolol & 224 \\
6. & Amlodipin & 214 \\
7. & Vitamin B kompleks & 205 \\
8. & Na diklofenak & 143 \\
9. & Ramipril & 113 \\
10. & Allopurinol & 105 \\
\hline
\end{tabular}


Tabel 6. Jumlah pasien geriatri berdasarkan jumlah macam obat yang digunakan

\begin{tabular}{ccc}
\hline Jumlah Obat & Jumlah Pasien & $\%$ \\
\hline $1-4$ & 218 & 35.28 \\
$5-7$ & 368 & 59.55 \\
$\geq 8$ & 32 & 5.17 \\
& 618 & 100 \\
\hline
\end{tabular}

Poliklinik jantung merupakan poliklinik yang paling banyak dikunjungi oleh pasien geriatri, yaitu 278 orang (44.98\%). Sedangkan poliklinik khusus geriatri merupakan poliklinik khusus bagi pasien yang berumur $\geq 60$ tahun yang memiliki komorbid penyakit yang banyak. Sebanyak 15 orang melakukan kunjungan sebanyak 2 (dua) poliklinik, sehingga pasien ini mendapatkan peresepan obat yang banyak (12 macam obat). 400 pasien (64.72\%) mendapat obat $\geq 5$ macam. Poliklinik jantung sebanyak 213 (76.61\%) pasien merupakan polifarmasi dan 28 (10\%) pasien mendapatkan obat $\geq 8$ macam obat.

\section{PEMBAHASAN}

Penelitian ini mendapatkan polifarmasi pada 400 pasien (64.72\%) rawat jalan dipoliklinik RS. M.Djamil. Alasan polifarmasi pada pasien geriatri adalah penyakit kronis yang multipatologi, obat diresepkan oleh beberapa dokter, kurang koordinasi dalam pengelolaan pengobatan, gejala yang dirasakan pasien kadang tidak jelas, pasien kadang sering meminta resep, dan pemberian obat untuk menghilangkan efek samping obat justru diberikan obat baru. Prevalensi polifarmasi berbeda dalam berbagai penelitian, tergantung pada definisi polifarmasi . Definisi polifarmasi yang kita gunakan adalah penggunaan secara bersamaan $\geq 5$ macam jenis obat, karena cutoff ini telah dikaitkan dengan hasil efek samping obat yang terkait dengan terjadinya kelemahan, resiko jatuh, cacat, dan kematian pada pasien geriatri. ${ }^{(2)}$
Prevalensi polifarmasi sebanyak $64.72 \%$ termasuk angka yang tinggi. Dalam penelitian sebelumnya di Jerman hanya $10 \%$ prevalensi polifarmasi, disini pengobatan berbasis pada asuransi kesehatan. Di Norwegia prevalensi penggunaan polifarmasi sebanyak $47 \%$ dalam penanganan penyakit, dan $57 \%$ polifarmasi di swedia pada pasien geriatric yang berumur lebih dari 75 tahun. Tingginya angka polifarmasi pada penelitian ini mungkin karena penelitian ini dilakukan pada pusat pengobatan rujukan dari berbagai daerah karena memilki penyakit yang rumit atau multimorbiditas. Mungkin juga akibat pengobatan yang diberikan secara gratis, sedangkan dinegara-negara eropa pasien seringkali harus membeli obat atau membayar biaya resep obat. Kunjungan lebih dari satu poliklinik akibat multimorbiditas juga merupakan faktor pemberian polifarmasi pada pasien. ${ }^{(12)}$

Penyakit yang banyak diderita oleh pasien geriatri adalah penyakit cardiovaskular seperti Atrial fibrilasi (AF), Penyakit Jantung Koroner, Gagal Jantung, hipertensi, serta penyakit diabetes melitus, penyakit paru-paru, arthritis, patah tulang, serta keganasan. Ini semua merupakan penyakit kronis yang perlu kontrol yang ketat terhadap penyakitnya, penyakit geriatri kebanyakan bersifat endogenik, multipel, kronik, bergejala atipik dan rentan terhadap penyakit atau komplikasi yang lain. Pada pasien geriatri, berbagai perubahan fisiologik pada organ dan sistem tubuh akan mempengaruhi tanggapan terhadap obat. Berbagai perubahan tersebut disebut dengan perubahan farmakokinetik, farmakodinamik, dan hal khusus lain yang merubah perilaku obat didalam tubuh. (1) (6)

Risiko terjadinya interaksi obat meningkat sejalan dengan obat yang diresepkan. Pasien dengan penyakit kritis dan pasien geriatri berisiko tinggi untuk mengalami interaksi obat 
bukan hanya karena mengkonsumsi obat yang lebih banyak, tetapi juga karena adanya gangguan mekanisme homeostasis yang tidak memungkinkan untuk menetralkan beberapa efek yang tidak diinginkan. ${ }^{(8)}$

Polifarmasi terbanyak adalah 12 macam obat yang didapat oleh beberapa orang pasien. Obat-obat yang didapat adalah Glikuidon, simvastatin, sodium bicarbonate, allopurinol, furosemid, aspirin, bisoprolol, telmisartan, amlodipin, lansoprazol, sukralfat, cefixime. Interaksi obat yang serius pada pasien ini adalah amlodipin dengan simvastatin. Amlodipin meningkatkan kerja simvastatin dan interaksi ini mengancam keselamatan jiwa yang serius, berpotensi untuk meningkatkan risiko miopati/rhabdomyolisis dan membatasi dosis simvastatin tidak lebih dari $20 \mathrm{mg} /$ hari disaat yang sama saat digunakan. Efek yang signifikan yang harus dimonitor ketat adalah toleransi antara aspirin dan gliquidon. Aspirin meningkatkan efek dari gliquidon dengan mekanisme yang tidak diketahui yaitu meningkatkan risiko hipoglikemia. Sodium bikarbonat dan allopurinol menghambat absorpsi gastrointestinal. Telmisartan dan bisoprolol dan aspirin meningkatkan kadar serum potasium. Aspirin, bisoprolol dan furosemid menurunkan kadar serum potasium. Sedangkan efek minor atau interaksi yang tidak signifikan adalah cefixime dengan aspirin, cefixime dapat meningkatkan efek dari aspirin dengan meningkatkan kompetisi tingkat keasaman obat (anionic) pada renal tubular clearance. ${ }^{\left({ }^{(8)}(11)\right.}$

Kebutuhan untuk mengurangi pemberian polifarmasi, studi longitudinal telah menunjukkan bahwa polifarmasi semakin meningkat selama bertahun-tahun. Pasien polifarmasi sering tidak mematuhi obat yang diresepkan. Ketidakpatuhan ini meningkatkan secara linier jumlah obat yang digunakan oleh pasien menjadi $80 \%$ dengan satu obat dibanding 20\% dengan enam atau lebih obat yang diberikan. Strategi untuk mengurangi pemberian obat dan pemahaman terhadap kelompok penyakit yang mengharuskan pemberian polifarmasi perlu dimengerti oleh setiap dokter terhadap pasien-pasien geriatri. Kunjungan rumah serta umpan balik berupa penjelasan dari dokter dan mengetahui prinsip pemberian obat yang benar untuk pasien usia lanjut merupakan alasan untuk tidak menutup kemungkinan menghindari polifarmasi. ${ }^{(4)}(5)$

Penelitian ini memiliki keterbatasan, yaitu belum dapat mencatatkan secara terperinci kelompok penyakit yang diderita oleh pasien geriatri, dan tidak menjelaskan apakah pasien patuh dalam minum obat. Efek samping obat serta interaksi obat dengan makanan, obat dengan obat, dan obat dengan penyakit juga belum dilakukan pada penelitian ini. Namun kekuatan pada penelitian ini adalah dapat melihat gambaran dari hubungan penyakit kronis yang multipatologi dengan prevalensi polifarmasi pada pasien geriatric yang memiliki kontrol teratur ke poliklinik RS M.Djamil dalam satu bulan.

\section{SIMPULAN}

Pada penelitian ini penyakit jantung memiliki tingkat yang tinggi untuk polifarmasi dan memiliki risiko ketergantungan obat dari polifarmasi.

\section{UCAPAN TERIMA KASIH}

Terimakasih yang sedalam-dalamnya kepada Direktur RSUP Dr.M.Djamil Padang dan kepala bagian rekam medis beserta staf yang telah memberikan izin untuk pengambilan data penelitian sehingga penelitian ini dapat diselesaikan. 


\section{DAFTAR PUSTAKA}

1. Hanlan JT, Handler SM, Maher RL, Schmader KE. Textbook of geriatric medicine and gerontology. Edisi ke-7. Elsevier inc; 2009.hlm.880-5.

2. Salih SB, Yousuf M, Durihim H. Prevalence and associated factors of polypharmacy among adult Saudi medical outpatient at a tertiary care center. J Family Community Med. 2013;20(3):162-7.

3. Nobili A, Marengoni A, Tettamanti M, Salerno F, Pasina L, Franhi C. Association between clusters of disease and polypharmacy in hospitalized elderly patients: Result from the Reposi study. Eur J Intern Med. 2011;22(6):597-602.

4. Direktorat Bina Farmasi Komunitas dan Kliniik. Pedoman pelayanan farmasi (tatalaksana terapi obat) untuk pasien geriatri Jakarta: Departemen Kesehatan Rl; 2004.

5. Supartondo, Govinda RA. Pedoman memberi obat pada pasien geriatri serta mengatasi masalah polifarmasi. Dalam: Sudoyo AW, Setiyohadi B, Alwi I, Simadibrata $M$, Setiati $S$, editor (penyunting). Buku ajar ilmu penyakit dalam. Edisi ke-6. Jakarta: Internal Publishing; 2014.hIm.37146.
6. Thanacoody. Drug interaction. In Clinical Pharmacy and Therapeutic. Edisi ke-5. London; 2012. hlm. 50-61.

7. Mallet L, Spinewine A, Huang A. The challenge of managing drug interactions in elderly people. Lancet. 2007 Jul; 370(9582):185-91.

8. Rouledge PA, O'Mahony MS, Woodhouse KW. Adverse drug reactions in elderly patient. $\mathrm{Br} \mathrm{J}$ Clin Pharmacol. 2004 Feb; 57(2):121-6.

9. Hilmer SN, Gnjidic D. The effect of polypharmacy in older adults. Clin Pharmacol Ther. 2009 Jan; 85(1):86-98.

10. Ningsih MC. Interaksi obat pada pasien di Poliklinik Geriatri Perjan RS DR. Cipto Mangunkusumo (skripsi). Jakarta: Universitas Indonesia; 2004.

11. Yuliani E. Interaksi Obat pada pasien geriatri yang menderita penyakit jantung dan penyakit dalam di Instalasi rawat inap B teratai RS Fatmawati Periode Oktober-November 2012 (skripsi). Jakarta: UIN Syarif Hidayatullah; 2013.

12. Grimmsmann T, Himmel W. Polypharmacy in primary care practices: an analysis using a large health insurance database. Pharmacoepidemiol Drug Saf. 2009 Dec;18(12):1206-13. 